UDC 539.3

Ahmad Rahbar Ranji ${ }^{1}$, PhD, Assoc. Prof., Azar Esmaeli $^{2}$

${ }^{1}$ Department of Maritime Engineering, AmirKabir University of Technology, 424 Hafez Ave., Tehran, 15914, Iran, e-mail: rahbar@aut.ac.ir

${ }^{2}$ Department of Civil Engineering, Bandar Abbas Branch, Islamic Azad University, Bandar Abbas, Iran

\title{
BLAST LOAD RESPONSE OF ONE-WAY REINFORCED CONCRETE SLABS RETROFITTED WITH FIBER REINFORCED PLASTIC
}

\begin{abstract}
А. Рахбар Ранджи, А. Есмаелі. Реакція на ударне навантаження односторонніх залізобетонних плит, модифікованих пластиком, армованим волокном. Основною метою сучасної роботи $є$ дослідження структурної поведінки односторонніх залізобетонних плит, модифікованих пластиком, армованим волокном. Модифікація проводиться для підвищення міцності на згин та зсув, покращення стримування та усування пошкоджень, викликаних корозією та розтріскуванням. При модифікації залізобетонних плит ПАВ часто використовується для підвищення міцності на згин, додавши його на сторону розтягування плити в області з максимальним анкером, що призводить до значного збільшення потужності поглинання енергії плити. Метод кінцевих елементів (МКЕ) широко використовується в різних областях для будівельного проектування, в електротехнічній промисловості, теплоенергетиці та машинобудуванні. У випадку аналізу наслідків вибуху через надмірну вартість, небезпеку експериментів та надзвичайно коротку тривалість випробування, чисельне моделювання є більш бажаним. Використовується процедура детального аналізу динаміки, яка базується на застосуванні правила явного інтегрування разом із використанням масивів матриць діагональних («зосереджених») елементів, що є обчислювально ефективною для аналізу великих моделей з відносно короткою динамічною відповіддю та для аналізу надзвичайно переривчастих подій або процесів. Комп’ютерний код ABAQUS використовується для аналізу, та результати порівнюються з наявними експериментальними результатами в літературі та спостерігається гарна відповідність. Також можна зробити висновок, що чисельний метод, використаний у цьому дослідженні, добре узгоджується з експериментальною роботою. Досліджено вплив різних геометричних параметрів, включаючи кількість шарів, орієнтацію волокон та співвідношення сторін плити. На відміну від доступних експериментальних результатів, показано, що методи моделювання мають високу точність. Встановлено, що незалежно від орієнтації волокон, змішення центру плити буде суттєво зменшено. Коли кут орієнтації волокон по відношенню до головного несучого напрямку плити складає $\left[-20^{\circ}, 20^{\circ}\right]$, вибухова міцність плити $\epsilon$ максимальною. Для плит із низьким співвідношенням сторін, чим більше число шарів, тим вище вибухова міцність. Для плит із високим співвідношенням сторін відсутні значні відмінності між різними структурами волокна та збільшення кількості шарів не впливає на вибухову міцність плит.

Ключові слова: вибухове навантаження; шар ПАВ; метод кінцевих елементів; залізобетонна плита; модифікація
\end{abstract}

Ahmad Rahbar Ranj, Azar Esmaeli. Blast load response of one-way reinforced concrete slabs retrofitted with Fiber reinforced plastic. The main aim of present work is to investigate structural behavior of one-way reinforced concrete slabs retrofitted with fiber reinforced plastic. Retrofitting is done to enhance bending and shear strength, to increase confinement and to repair damages caused by corrosion and cracking. In retrofitting RC slabs FRP is often used to enhance bending strength by putting it on the tensile side of the slab in the region with maximum anchor, which leads to significant increase in slab's energy absorption capacity. Finite Element Method (FEM) is widely used in different fields for structural, electrical, heat, and mechanical engineering. In the case of blast analysis, due to excessive cost, the danger of experiments and extremely short duration of the test, numerical simulation is more attractive. Explicit dynamics analysis procedure based on the implementation of an explicit integration rule together with the use of diagonal ("lumped") element mass matrices is used, which is computationally efficient for the analysis of large models with relatively short dynamic response and for the analysis of extremely discontinuous events or processes. Computer code ABAQUS is used for the analysis and the results are compared with available experimental results in the literature and good agreement has been observed. Also it can be concluded that numerical method used in this study has good agreement with experimental work. Influence of different geometrical parameters including number of layers, orientation of the fibers and the aspect ratio of slab has been investigated. Upon comparison with available experimental results, it is shown that modeling techniques have good accuracy. It is found that regardless of the orientation of the fibers, displacement of the center of slab would be reduced significantly. When fibers orientation angle with respect to the main load bearing direction of the slab is $\left[-20^{\circ}, 20^{\circ}\right]$, the blast strength of the slab is maximum. For slabs with low aspect ratio, the more the number of layers, the higher the blast strength. For slabs with high aspect ratio, there is no significant difference between different fiber arrangements and increasing number of layers has no significant effect on blast strength of slabs.

Keywords: Blast Load; FRP Layer; Finite Element Method; Reinforced Concrete Slab; retrofitting

Introduction. Generally, concrete is known as a relatively high blast resistance material compared to other constructional materials. However, some existing concrete structures require retrofitting during their service life to improve their strength against impact and blast loads. The most popular and common method for structural retrofitting is adhesive bonding of Fiber Reinforced Polymer (FRP) to the external surface of the Reinforced Concrete (RC) members [1-2].

$$
\text { DOI: 10.15276/opu.2.55.2018.05 }
$$

(c) 2018 The Authors. This is an open access article under the CC BY license (http://creativecommons.org/licenses/by/4.0/). 
Retrofitting is done to enhance bending and shear strength, to increase confinement and to repair damages caused by corrosion and cracking. Due to low weight, ease of application and high tensile strength against harsh environmental conditions FRP has been largely used as a main retrofitting material. In retrofitting RC slabs FRP is often used to enhance bending strength by putting it on the tensile side of the slab in the region with maximum anchor, which leads to significant increase in slab's energy absorption capacity [3]. Due to high risk of terrorist attacks, design and control of structures under blast load has been increasingly admitted as a standard practice.

Literature review and Formulation of the problem. Several experimental research works were done to investigate blast strength of RC structures retrofitted with FRP. Muzsinsky and Purcell [4] studied some RC walls retrofitted with carbon and glass FRP under $860 \mathrm{Kg}$ explosive TNT at short distances and found out that the retrofitted walls show higher resistance to blast loads. Lu et al. [5] tested four RC slabs retrofitted with FRP under blast load and concluded that retrofitting the slab on both sides was much more effective than retrofitting at one side. Wu et al. [6] tested two RC slabs and showed that retrofitting at one side did not increase blast strength of the slab. Silva and Lu [7] investigated the possibility of using new composite materials to improve the strength of slabs against blast load in one sided reinforced concrete. The results showed that when the slabs were retrofitted only at one side there was no significant increase in strength against blast, however, in the slabs with both sides retrofitted a significant increase in blast strength was observed. Bibiana and Luege [8] experimentally and numerically studied the behavior of concrete pavement slabs under blast shock loads on the top of the pavement to investigate damages and occurrence of cracks.

Low and Hao [9] examined reliability of RC slabs against blast loads using numerical modeling and found that the impact of the blast load on the structures depends on many parameters and was not predictable. Tai et al. [10] proposed some empirical equations to predict damage mechanism and dynamic response of RC slabs based on numerical studies using LSDYNA. Low et al. [11] conducted a numerical study on RC slab retrofitted by composite sheets under blast loads. Mosalam and Mosallam [12] carried out a numerical study on the behavior of RC slabs under blast load and examined the influence of different parameters including duration of loading and the effect of CFRP modification on damage density. Jin-Won et al. [3] analyzed the strength of retrofitted slabs with GFRP against blast using LSDYNA. Castedo et al. [13] tested eight slabs and compared the results obtained from numerical modeling with experiments. Li et al. [14] tested two types of concrete, Ultra-High Performance Concrete (UHPC) and Normal Strength Concrete (NSC), used in RC slabs, and the results confirmed the effectiveness of the UHPC slab against blast loads. Yao et al. [15] investigated the anti-blast performance and characteristics of RC slabs damage with different reinforcement ratios through both experimental and numerical studies and concluded that the reinforcement ratio has a profound influence on the survivability of RC slabs when subjected to blast loading.

Purpose of the study. It is the main aim of present work to study the influence of geometrical parameters, including number of layers, the orientation of fibers and aspect ratio of slab on the behavior of RC slabs retrofitted with fiber reinforced under blast loading. Computer code ABAQUS is used and the optimum amount of FRP is determined.

Finite Element Analysis. Finite Element Method (FEM) is widely used in different fields for structural, electrical, heat, and mechanical engineering. In the case of blast analysis, due to excessive cost, the danger of experiments and extremely short duration of the test, numerical simulation is more attractive. In this study computer code ABAQUS [16] is used for analysis. Explicit dynamics analysis procedure based on the implementation of an explicit integration rule together with the use of diagonal ("lumped") element mass matrices is used which is computationally efficient for the analysis of large models with relatively short dynamic response and for the analysis of extremely discontinuous events or processes.

Failure model of concrete material. Orakcal et al. [17] and Shima et al. [18] models are used to express the compressive and tensile stress-strain behaviors of concrete, respectively (Fig. 1). Damage plasticity model, which is widely used as a failure criterion of concrete shear walls, is employed. This model uses the isotropic damaged elasticity concept in combination with isotropic tensile and compressive plasticity to represent the inelastic behavior of concrete. It is assumed that two main failure 
mechanisms are tensile cracking and compressive crushing of the concrete material. The degradation of the elastic stiffness induced by plastic straining both in tension and compression are taken into consideration. This model is appropriate for any loading, including cyclic loading. Reduction of the elastic hardness is compensated by considering plastic strain in tension and compression. This model is available in ABAQUS [16].

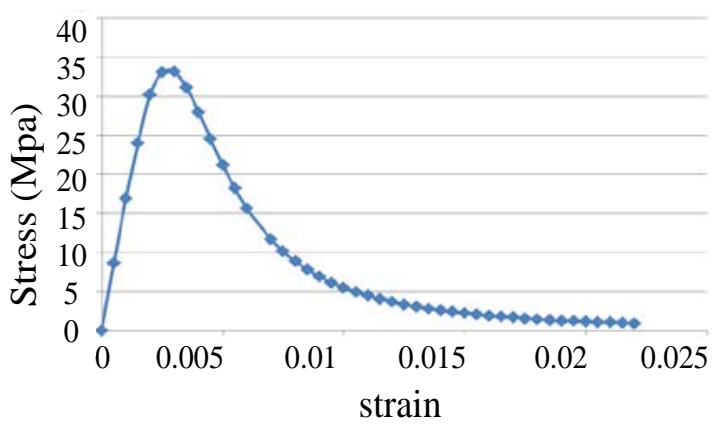

$a$

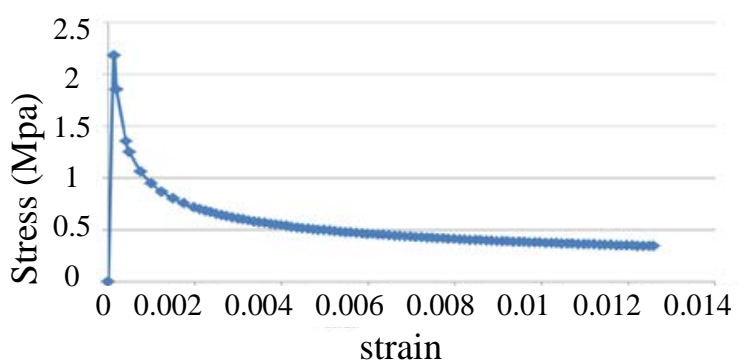

$b$

Fig. 1. Stress-strain relation of concrete considered in this study: Compression [17] (a), Tension [18] (b)

FE Model of slab. The reinforcement bars are modelled with T3D2 element, which is a 2-node, 3D linear displacement truss elements and transmits an axial force. For the nonlinearity of the selected steel material the available kinematic hardening is used. The concrete slab is modelled with C3D8 brick element, which has 8 nodes and is suitable for blast analysis with the possibility of damage. FRP is modelled with s4 shell element, which has 4 nodes with 6 degrees of freedom. Fig. 2 shows FEM of an RC slab.

The slab has dimensions of $a \times b \times h$, which are the length, width and thickness of the slab, respectively. Cartesian coordinate system with its origin at one corner is used. Since all RC slabs, which have been studied in this work are one-way slabs, at edges $x=0$ and $x=a$, displacement in $y$ and $z$ directions are restrained.

For FEA adequate size of mesh should be selected. Though by reducing the size of mesh, the accuracy of results would increase, however, the time of calculation and cost of analysis also increase. Therefore, a compromise between accuracy and time should be selected. This is usually done by a

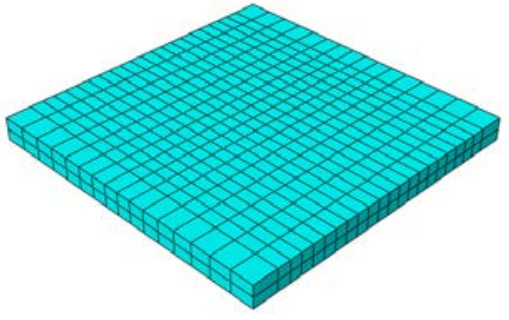

Fig. 2. FEM of a RC slab

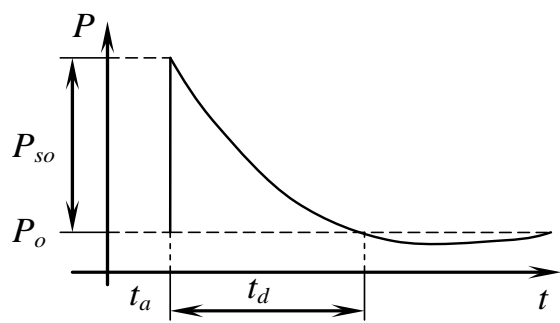

Fig. 3. Shock wave distribution [19] convergence analysis or by comparison of numerical results with some experiments. Here the latter approach is used and adequate sizes of mesh are determined as follows:

- concrete with size of mesh $60 \times 60 \times 60 \mathrm{~mm}$,

- reinforced bars with size of mesh $25 \mathrm{~mm}$,

- FRP with size of mesh $100 \times 100 \mathrm{~mm}$.

Modelling of the blast load. Explosion loading wave is defined by three parameters of shape of wave, maximum pressure, $p_{s o}$, and positive wave duration, $t_{d}$, which is the time that pressure reaches zero. Depending on the source of the explosion, the generated waves are divided into shock wave and pressure wave. In shock wave the pressure of gasses formed by the explosion is developed by emission from the source of the explosion. It increases to maximum pressure, $p_{s o}$, and decreases to environmental pressure which is defined as positive phase (Fig. 3). 
Negative pressure phase is relatively small and gradual and has negligible effect on deformation and damage of structures. This is why it is mostly ignored [19] and usually an equivalent rectangle wave distribution is considered for positive phase only. In order to find the maximum pressure induced by explosion and to achieve a criterion for determining the severity of the damage, scale distance, $\mathrm{Z}$, is defined as follows [19]:

$$
\begin{gathered}
\rho_{s o}=\frac{6.7}{z^{3}}+1\left(\rho_{s o} G>10 \mathrm{~kg} / \mathrm{cm}^{2}\right), \\
\rho_{s o}=\frac{0.975}{Z}+\frac{1.455}{z^{2}}+\frac{5.95}{Z^{3}}-0.019\left(0.1<\rho_{s o}<10 \mathrm{~kg} / \mathrm{cm}^{2}\right), \\
Z=\frac{R}{W^{\frac{1}{3}}},
\end{gathered}
$$

where $R$ is the distance of explosion charge to the desired location (m), $W$ is explosive charge weight per TNT equivalent weight $(\mathrm{kg})$. Use of $Z$ offers a concise and effective expression of explosion wave over a wide range of scenarios. Fig. 4 demonstrates the form of explosion's wave distribution for different distances of explosion charge. As expected, pressure is uniform for larger distance of explosion charge, however, reducing this distance leads to significant increase of maximum pressure at the centre of slab. The pressure wave in the center of slab reaches maximum value and decreases towards the sides [7]. In this study the pressure wave distribution shown in Fig. 4 is used.

Verification of FEM accuracy. In order to validate FEM two experimental works, conducted to examine the behavior of RC slabs under blast loading condition, are reconsidered. Wu et al. [20] and Jones et al. [21] have tested several laboratory samples. One of the slabs with dimensions of $2000 \times 1000 \times 100 \mathrm{~mm}$ and reinforcement percent of 1.34 is revisited (Fig. 5).

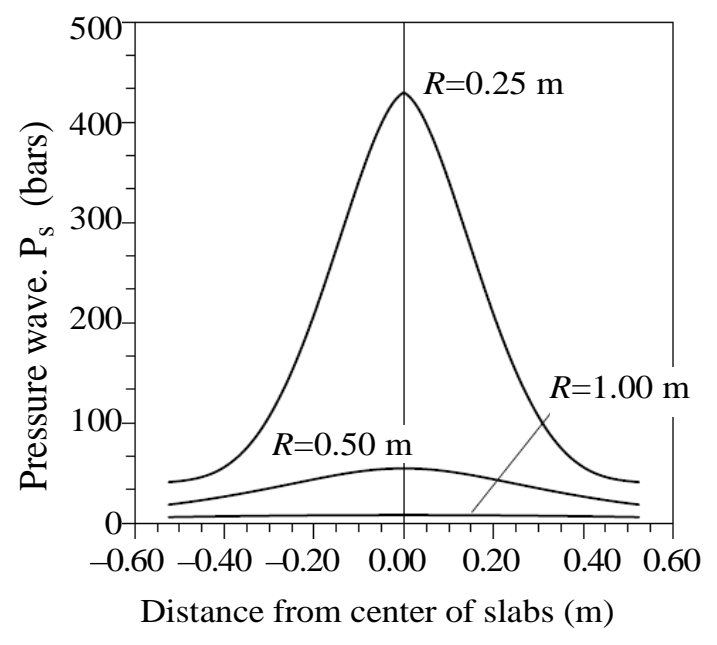

Fig. 4. Distribution of shock wave for different distances of explosion location, $R$ [7]

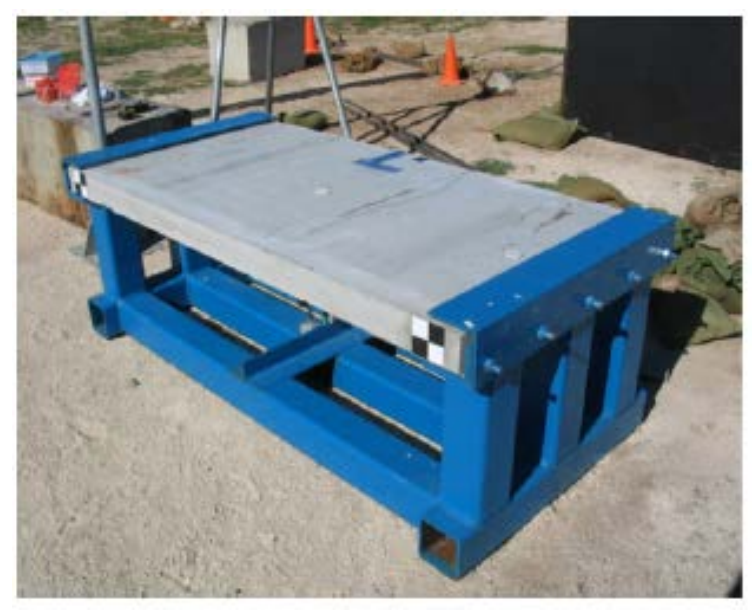

Fig. 5. Tested slab and method of testing used by Wu et al [20] and revisited by Jones et al [21]

The concrete compressive strength and steel yield strength were $39.5 \mathrm{Mpa}$ and $600 \mathrm{Mpa}$, respectively. The distance of explosion charge was $3 \mathrm{~m}$ above the center of the slab and $1.1 \mathrm{~kg}$ of explosion charge was used. Fig. 6 shows the displacement history taken from experiment [20] and corresponding curve obtained from finite difference method [21]. Fig. 7 shows the history of the displacement at the center of the slab obtained by FEM in this study. As can be seen both curves of Figs. 6 and 7 have the same trend and maximum displacement measured in the experiment was $2 \mathrm{~mm}$ which is very close to the value obtained in this study by FEM as $2.24 \mathrm{~mm}$. Therefore, it can be concluded that FEM and experimental work have good agreements. 


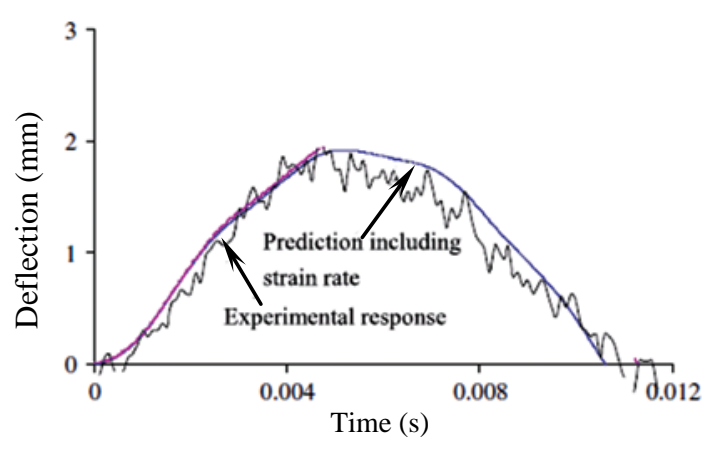

Fig. 6. Displacement history of an RC slab under blast load (experiment [20] and finite difference method [21])

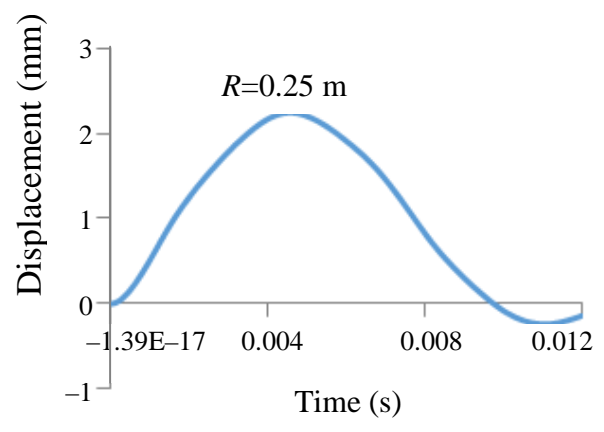

Fig. 7. Displacement history of the RC slab determined by FEM in this study

Table 1

Silva and Lou [7] on one-way RC slabs with dimensions of $1200 \times 1200 \times 90 \mathrm{~mm}$ and with three $10 \mathrm{~mm}$ diameter reinforcement bars as main bending reinforcements in the bottom side. The compressive strength of concrete was $28 \mathrm{Mpa}$, and the yield stress of bars and modulus of elasticity were $414 \mathrm{Mpa}$ and $200 \mathrm{Gpa}$, respectively. They have examined six different retrofitting schemes. One of the samples, which were retrofitted with FRP sheets of carbon with thickness $0.165 \mathrm{~mm}$ at top and bottom sides of the slab, is reconsidered. The properties of FRP material are shown in Table 1.

The distance of explosion charge was $300 \mathrm{~mm}$ above the center of slab and explosion charge was equal to $1.35 \mathrm{~kg}$ of TNT explosive (Fig. 8). Maximum displacement measured in the experiment was $24.58 \mathrm{~mm}$ and the corresponding value in FEM is $21.65 \mathrm{~mm}$. Again, it can be concluded that numerical method used in this study has good agreement with experimental work.

Parametric study. In order to determine the effect of different geometrical parameters on the blast strength of RC slabs, five slabs with dimensions $1200 \times 1200 \times 90 \mathrm{~mm}$, $1800 \times 1200 \times 90 \mathrm{~mm}, \quad 2400 \times 1200 \times 90 \mathrm{~mm}$, $2400 \times 1800 \times 90 \mathrm{~mm}$, and $2400 \times 600 \times 90 \mathrm{~mm}$ with FRP arrangements of, $\left[0^{\circ}\right],\left[20^{\circ},-20^{\circ}\right],\left[40^{\circ},-40^{\circ}\right]$, and $\left[0^{\circ}, 90^{\circ}\right]$ with one layer of FRP with thickness $0.165 \mathrm{~mm}$ at both top and bottom sides of slabs and one slab without any retrofitting under blast load with the same characteristics as Silva and Lou [7] are considered. Figs. 9 and 10 show two different FRP orientation of retrofitting RC slab with angles $\left[0^{\circ}, 90^{\circ}\right]$ and $\left[-20^{\circ}, 20^{\circ}\right]$, respectively.

Table 2 shows the maximum displacement at the center of slabs under blast load. As can be seen, maximum displacement of retrofitted slabs is reduced significantly regardless of FRP arrangements and size of slabs. Unidirectional FRP arrangement, $\left[0^{\circ}\right]$, in the direction of the maximum bending moment has the least influence on blast strength of slab. FRP with $\left[-20^{\circ}, 20^{\circ}\right]$ orientation is the optimum arrangement of FRP for any size of the slab. For slabs with larger aspect ratio, $2400 \times 600 \mathrm{~mm}$, there are no significant differences between different FRP arrangements. 


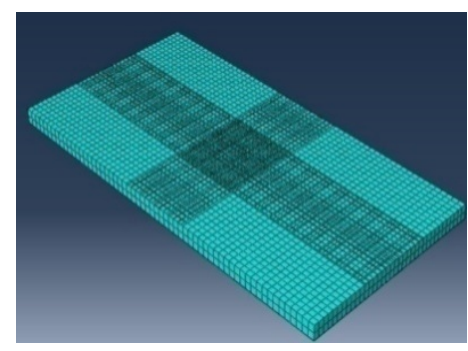

Fig. 9. FE model of an $R C$ slab retrofitted with $\left[0^{\circ}, 90^{\circ}\right.$ angle of orientation of FRP

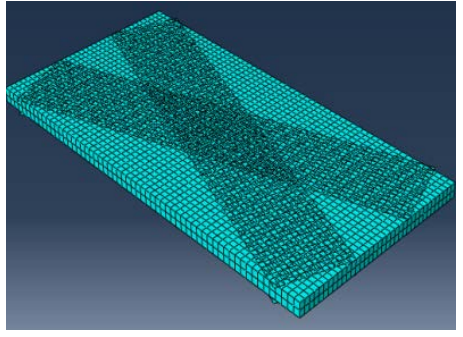

Fig. 10. FE model of the RC slab retrofitted with [-20, 20 ' angle of orientation of FRP

Table 2

Maximum displacement, $\mathrm{mm}$, at the center of RC slabs under blast load

\begin{tabular}{c|c|c|c|c|c}
\hline \multirow{2}{*}{$\begin{array}{c}\text { FRP } \\
\text { orientation }\end{array}$} & \multicolumn{5}{|c}{ Slab dimensions, $a \times b \times 90 \mathrm{~mm}$} \\
\cline { 2 - 6 } & $1200 \times 1200$ & $1800 \times 1200$ & $2400 \times 1200$ & $2400 \times 1800$ & $2400 \times 600$ \\
\hline Not retrofitted & 74.21 & 146.51 & 145 & 72.19 & 92.51 \\
\hline$\left[0^{\circ}\right]$ & 10.19 & 21.04 & 16.9 & 21.04 & 3.98 \\
\hline$\left[0^{\circ}, 90^{\circ}\right]$ & 8.4 & 17.84 & 13.3 & 17.84 & 3.44 \\
\hline$\left[-20^{\circ}, 20^{\circ}\right]$ & 7.3 & 16.4 & 13.5 & 16.40 & 2.77 \\
\hline$\left[-40^{\circ}, 40^{\circ}\right]$ & 11.39 & 25.1 & 28.99 & 25.10 & 3.46 \\
\hline
\end{tabular}

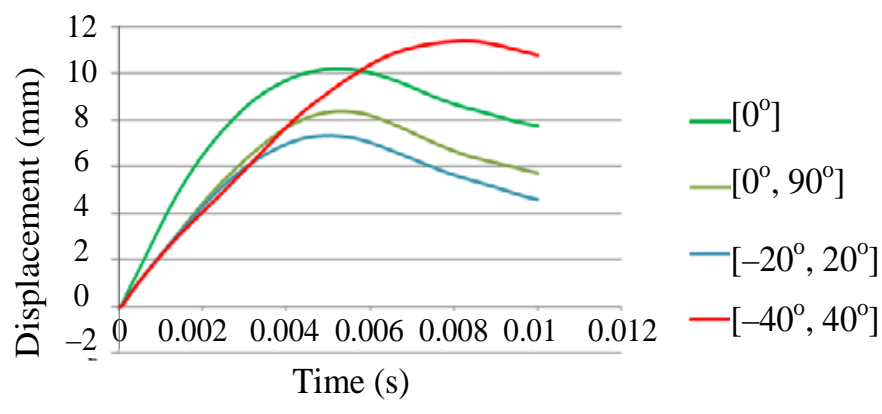

Fig. 11. Displacement history of centre of $1200 \times 1200 \times 90 \mathrm{~mm}$ slab under blast load for different FRP arrangements
Fig. 11 shows the displacement history of centre of $1200 \times 1200 \times 90 \mathrm{~mm}$ slab under blast load for different FRP arrangements. It can be seen that at the beginning when the pressure is low, the deformation of all slabs except unidirectional retrofitted slab, $\left[0^{\circ}\right]$, are the same. By increasing pressure the difference between various arrangements envisages. Fig. 12 shows deformation and strain distribution of this slab.

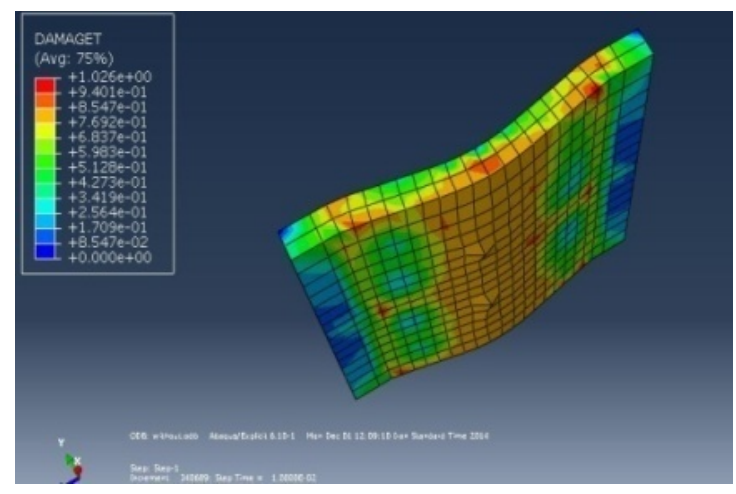

$a$

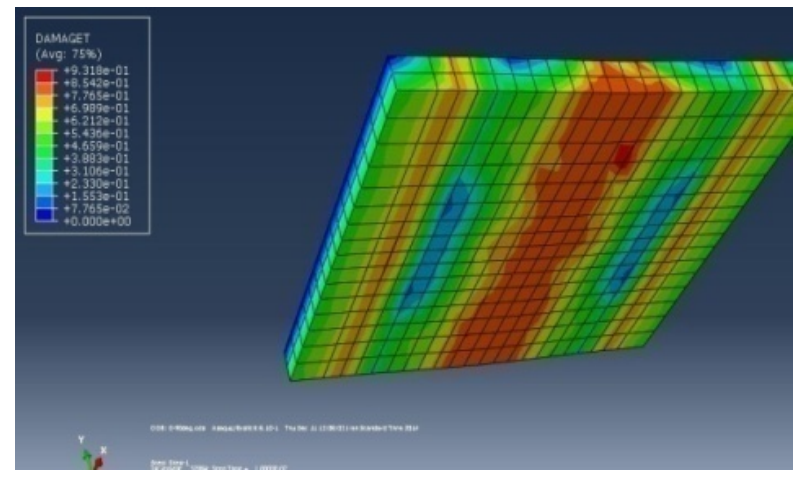

$b$

Fig. 12. Deformation and strain distribution in an RC slab with dimension $1200 \times 1200 \times 90 \mathrm{~mm}$ under blast load: Not Retrofitted (a), Retrofitted by FRP at angle of $\left[0^{\circ}, 90^{\circ}\right]$ (b) 
In order to determine the effect of thickness of FRP, above mentioned slabs and orientation of FRP's with one to five number of layers at both sides of the slabs are considered. To characterize the effect of retrofitting on blast strength of RC slabs, relative increase of blast strength is defined by a parameter as follows:

$R_{\mathrm{BL}}=\frac{\text { Maximum displacement of nonretrofitted slab }- \text { Maximum displacement of retrofitted slab }}{\text { Maximum displacement of nonretrofitted slab }} \times 100$.

Figs. $13-17$ show the relative increase of blast strength parameter, $R_{\mathrm{BL}}$, for different size of slabs and retrofitting arrangements. As can be seen, by increasing number of layers, blast strength of slabs increases regardless of different geometrical parameters, however, for number of layers more than two the rate of increase of blast strength diminishes significantly. In other words, when number of layers is more than two, blast strength almost remains constant. Therefore, from an economical point of view, it can be claimed that the optimum number of layers for these types of slabs are two layers. Though the FRP arrangement of $\left[20^{\circ},-20^{\circ}\right]$ yields the maximum increase of blast strength for all slab dimensions, for slabs with higher aspect ratio the differences between different FRP arrangements decrease. For example, for slabs with aspect ratio of 1.33 and 1.5 there is no significant difference between FRP arrangements of $\left[20^{\circ},-20^{\circ}\right]$ and $\left[0^{\circ}, 90^{\circ}\right]$. For slabs with aspect ratio of 3 there is no significant difference between FRP arrangements of $\left[0^{\circ}\right],\left[20^{\circ},-20^{\circ}\right]$ and $\left[0^{\circ}, 90^{\circ}\right]$. For slabs with aspect ratio of 4 there is no significant difference between FRP arrangements of $\left[0^{\circ}\right],\left[20^{\circ},-20^{\circ}\right],\left[40^{\circ},-40^{\circ}\right]$ and $\left[0^{\circ}, 90^{\circ}\right]$.

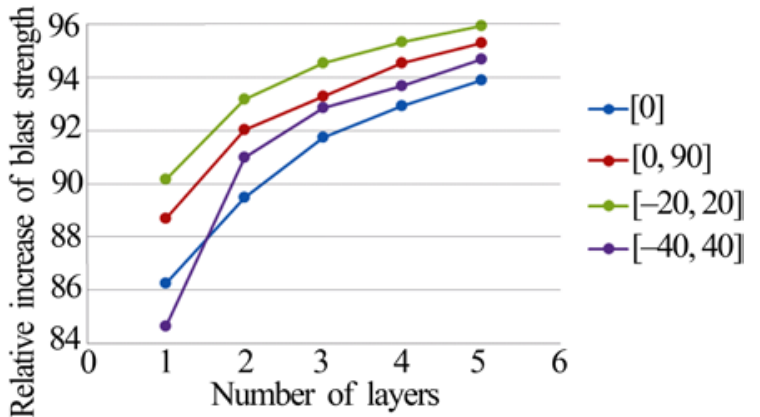

Fig. 13. Increase of blast strength in a slab $(1200 \times 1200 \times 90 \mathrm{~mm})$ with different number of layers of FRP under blast load

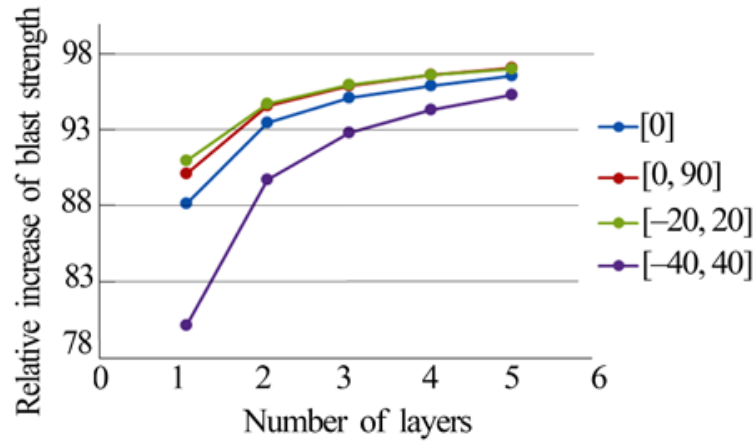

Fig. 15. Increase of blast strength in a slab $(1200 \times 2400 \times 90 \mathrm{~mm})$ with different number of layers of FRP under blast load

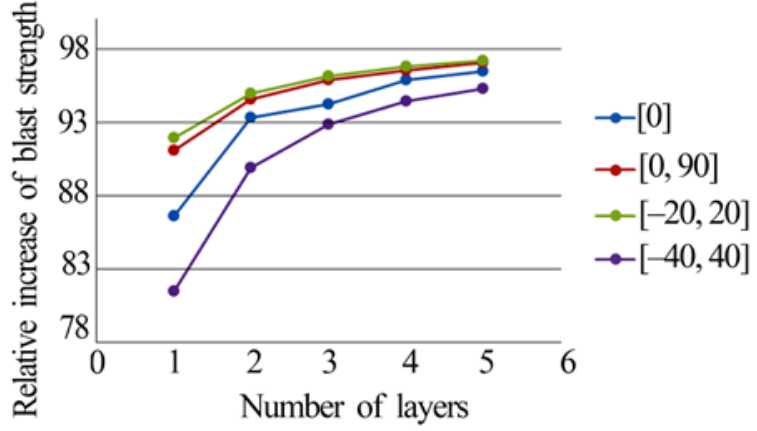

Fig. 14. Increase of blast strength in a slab $(1200 \times 1800 \times 90 \mathrm{~mm})$ with different number of layers of FRP under blast load

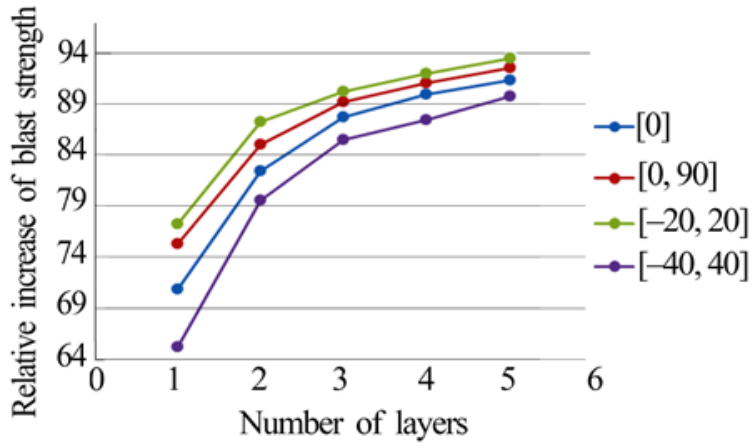

Fig. 16. Increase of blast strength in a slab $(2400 \times 1800 \times 90 \mathrm{~mm})$ with different number of layers of FRP under blast load 


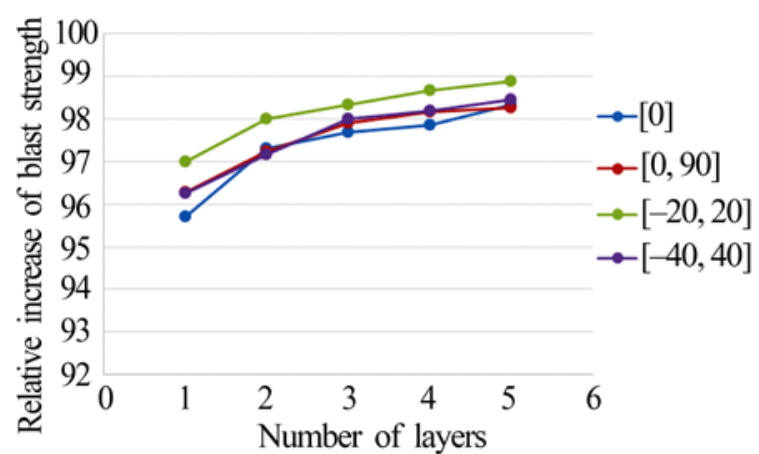

Fig. 17. Increase of blast strength in a slab $(2400 \times 600 \times 90 \mathrm{~mm})$ with different number of layers of FRP under blast load

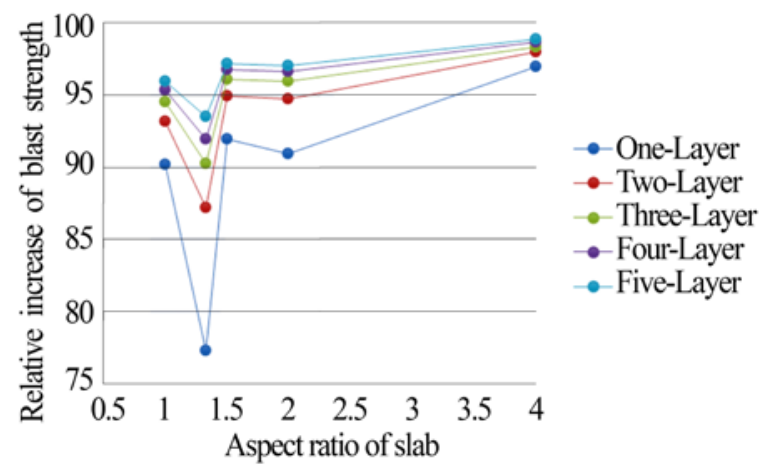

Fig. 18. Increase of blast strength in slabs with different number of layers of $\left[20^{\circ},-20\right.$ \% FRP arrangement under blast load

Fig. 18 shows relative increase of blast strength parameter, $R_{\mathrm{BL}}$, for different slab aspect ratio and number of layers with FRP arrangement of $\left[20^{\circ},-20^{\circ}\right]$. As can be seen, for slabs with low aspect ratio blast strength increases together with number of layers, however, in slabs with higher aspect ratio increasing number of layers has no significance on blast strength of RC slabs.

Conclusion. FEM is used to analyze the blast strength of retrofitted one-way RC slabs with FRP. Upon comparison with available experimental results, it is shown that modeling techniques have good accuracy. Different arrangement of FRP's, dimensions of the slab and different number of layers are considered and following results are achieved:

- Deformation of the center of RC slabs under blast loading retrofitted with FRP is far less than slabs without FRP.

- Regardless of dimensions of slabs and number of layers, when orientation angle of FRP's is $\left[-20^{\circ}, 20^{\circ}\right]$ with respect to the main bending direction of the slab, displacement is minimum and therefore retrofitting has maximum effect on the increase of blast strength of RC slabs.

- For slabs with high aspect ratio there are no significant differences between different FRP arrangements and number of layers.

- For slabs with low aspect ratio, as number of layers increases, blast strength also increases.

\section{Література}

1. Teng J.G., Chen J.F., Smith S.T., Lam L. Behavior and strength of FRP-strengthened RC structures: a state-of-the-art review. Proceedings of the Institution of Civil Engineers - Structures and Buildings. 2003. Vol. 156, Issue 1. P. 51-62. DOI: https//doi.org/10.1680/stbu.2003.156.1.51.

2. Wu Y.F., Huang Y. Hybrid bonding of FRP to reinforced concrete structures. Journal of Composites for Construction. 2008. Vol. 12, Issue 3. P. 266-273. DOI: https//doi.org/10.1061/(ASCE)10900268(2008)12:3(266).

3. Jin-Won Nam N., Ho-Jin K., Sung-Bae K., Y. Na-Hyun, Jang-Ho K. J. Numerical evaluation of the retrofit effectiveness for GFRP retrofitted concrete slab subjected to blast pressure. Composite Structures. 2010. Vol. 92, Issue 5. P. 1212-1222. DOI: https//doi.org/10.1016/j.compstruct. 2009.10.031.

4. Muzsynski L., Purcell M. Composite reinforcement to strengthen existing concrete structures against air blast, Journal of Composites for Construction. 2003. Vol. 7, Issue 2. P. 93-97. DOI: https//doi.org/10.1061/(ASCE)1090-0268(2003)7:2(93).

5. Lu B., Silva P., Nanni A., Baird J. Retrofit for blast-resistant RC Slabs with composite materials. Missouri: University of Missouri-Rolla. 2005. Vol. 230. P. 1345-1360.

6. Wu C., Oehlers D.J., Wachl J., Glynn C., Spencer A., Matthew M., Day I. Blast Testing of RC Slabs Retrofitted with NSM CFRP Plates. Advances in Structural Engineering. 2007. Vol. 10, Issue 4. P. 397-414. DOI: https//doi.org/10.1260/136943307783239372 
7. Silva P.F., Lu B. Improving the blast resistance capacity of RC slabs with innovative composite materials. Composites Part B: Engineering. 2007. Vol. 38, Issue 5-6. P. 523-534. DOI: https//doi.org/10.1016/j.compositesb.2006.06.015.

8. Bibiana M.L., Luege M. Concrete pavement slab under blast loads. International Journal of Impact Engineering. 2006. Vol. 32. Issue 8. P. 1248-1266. DOI://doi.org/10.1016/j.ijimpeng.2004.09.005.

9. Low H.Y., Hao H. Reliability analysis of reinforced concrete slabs under explosive loading. Structural Safety. 2001. Vol. 23. Issue 2. P. 157-178. DOI: https//doi.org/10.1016/S0167-4730(01)00011-X.

10. Tai Y.S., Chu T.L., Hu H.T., Wu J.Y. Dynamic response of a reinforced concrete slab subjected to air blast load. Theoretical and Applied Fracture Mechanics. 2011. Vol. 56. Issue 3. P. 140-147. DOI: https//doi.org/10.1016/j.tafmec.2011.11.002.

11. Low H., Hao H., Ma G.W. Numerical Simulation of Dynamic Responses of RC Slabs Under Blast Loading. Int. symposium on strength theory. Application development \& prospects for 21 st century. 1998.

12. Mosalam M.K., Mosallam A.S. Nonlinear transient analysis of reinforced concrete slabs subjected to blast loading and retrofitted with CFRP composites. Composites Part B: Engineering. 2001. Vol. 32, Issue 8. P. 623-636. DOI: https//doi.org/10.1016/S1359-8368(01)00044-0.

13. Castedo R., Segarra P., Alanon A., Lopez L.M., Santos A.P. Sanchidrian J.A. Air blast resistance of full-scale slabs with different compositions: Numerical modeling and field validation. International Journal of Impact Engineering. 2015. Vol. 86. P. 145-156. DOI: https//doi.org/10.1016/j.ijimpeng. 2015.08.004.

14. Li J., Wu C., Hao H. An experimental and numerical study of reinforced ultra-high performance concrete slabs under blast loads. Materials \& Design. 2015. Vol. 82. P. 64-76. DOI: https//doi.org/10.1016/j.matdes.2015.05.045.

15. Yao S., Zhang D., Chen X., Lu F., Wang W. Experimental and numerical study on the dynamic response of RC slabs under blast loading. Engineering Failure Analysis. 2016. Vol. 86. P. 120-129. DOI: https//doi.org/10.1016/j.engfailanal.2016.04.027

16. ABAQUS standard user's manual. Ver. 6.10-1. 2010.

17. Orakcal K., Massone L.M., Wallace J.W. Analytical modelling of reinforced concrete walls for predicting flexural and coupled-shear-flexural responses. University of California, Los Angeles. PEER report. 2006.

18. Shima H, Chou L, Okamura H. Micro and macro models for bond in reinforced concrete. Journal of Faculty of Engineering. University of Tokyo. 1987. Vol. 39, Issue 2. P. 133-94.

19. May G.C., Smith P.D. Blast effects on buildings. Thomas Telford Ltd., London, E14 4 JD, 1995.121 p.

20. Wu C., Oehlers D.J., Rebentrost M., Leach J., Whittaker A.S. Blast testing of ultra-high performance fiber and FRP-retrofitted concrete slabs. Journal of Engineering Structures. 2009. Vol. 31. Issue 9. P. 2060-2069. DOI: https//doi.org/10.1016/j.engstruct.2009.03.020.

21. Jones J., Wu C., Oehlers D.J., Rebentrost M., Leach J., Whittaker A.S., Sun W., Marks S., Coppola R. Finite difference analysis of simply supported RC slabs for blast loadings. Journal of Engineering Structures. 2009. Vol. 31. Issue 12. P. 2825-2832. DOI: https//doi.org/10.1016/j.engstruct.2009.07.011.

\section{References}

1. Teng, J.G., Chen, J.F., Smith, S.T., \& Lam, L. (2003). Behavior and strength of FRP-strengthened RC structures: a state-of-the-art review. Proceedings of the Institution of Civil Engineers - Structures and Buildings, 156, 1, 51-62. DOI: https//doi.org/10.1680/stbu.2003.156.1.51.

2. Wu, Y.F., \& Huang, Y. (2008). Hybrid bonding of FRP to reinforced concrete structures. Journal of Composites for Construction, 12, 3, 266-273. DOI: https//doi.org/10.1061/(ASCE)10900268(2008)12:3(266).

3. Jin-Won Nam, N., Ho-Jin, K., Sung-Bae, K., Na-Hyun, Y. \& Jang-Ho, K. J. (2010). Numerical evaluation of the retrofit effectiveness for GFRP retrofitted concrete slab subjected to blast pressure. Composite Structures, 92, 5, 1212-1222. DOI: https//doi.org/10.1016/j.compstruct.2009.10.031.

4. Muzsynski, L., \& Purcell, M. (2003). Composite reinforcement to strengthen existing concrete structures against air blast. Journal of Composites for Construction, 7, 2, 93-97. DOI: https//doi.org/10.1061/(ASCE)1090-0268(2003)7:2(93).

5. Lu, B., Silva, P., Nanni, A., \& Baird, J. (2005). Retrofit for blast-resistant RC Slabs with composite materials. Missouri: University of Missouri-Rolla, 230, 1345-1360. 
6. Wu, C., Oehlers, D.J., Wachl, J., Glynn, C., Spencer, A., Matthew, M., \& Day, I. (2007). Blast Testing of RC Slabs Retrofitted with NSM CFRP Plates. Advances in Structural Engineering, 10, 4, 397-414. DOI: https//doi.org/10.1260 /136943307783239372.

7. Silva, P.F., \& Lu, B. (2007). Improving the blast resistance capacity of RC slabs with innovative composite materials. Composites Part B: Engineering, 38, 5-6, 523-534. DOI: https//doi.org/10.1016/j.compositesb.2006.06.015.

8. Bibiana, M.L., \& Luege, M. (2006). Concrete pavement slab under blast loads. International Journal of Impact Engineering, 32, 8, 1248-1266. DOI: https//doi.org/10.1016/j.ijimpeng.2004.09.005.

9. Low, H.Y., \& Hao, H. (2001). Reliability analysis of reinforced concrete slabs under explosive loading. Structural Safety, 32, 2, 157-178. DOI: https//doi.org/10.1016/S0167-4730(01)00011-X.

10. Tai, Y.S., Chu, T.L., Hu, H.T., \& Wu, J.Y. (2011). Dynamic response of a reinforced concrete slab subjected to air blast load. Theoretical and Applied Fracture Mechanics, 56, 3, 140-147. DOI: https//doi.org/10.1016/j.tafmec.2011.11.002.

11. Low, H., Hao, H., \& Ma, G.W. (1998). Numerical Simulation of Dynamic Responses of RC Slabs Under Blast Loading. Int. symposium on strength theory. Application development \& prospects for 21 st century.

12. Mosalam, M.K., \& Mosallam, A.S. (2001). Nonlinear transient analysis of reinforced concrete slabs subjected to blast loading and retrofitted with CFRP composites. Composites Part B: Engineering, 32, 8, 623-636. DOI: https//doi.org/10.1016/S1359-8368(01)00044-0.

13. Castedo, R., Segarra, P., Alanon, A., Lopez, L.M., Santos, A.P. \& Sanchidrian, J.A. (2015). Air blast resistance of full-scale slabs with different compositions: Numerical modeling and field validation. International Journal of Impact Engineering, 86, 145-156. DOI: https//doi.org/10.1016/j.ijimpeng.2015.08.004.

14. Li, J., Wu, C., \& Hao, H. (2015). An experimental and numerical study of reinforced ultra-high performance concrete slabs under blast loads. Materials \& Design, 82, 64-76. DOI: https//doi.org/10.1016/j.matdes.2015.05.045.

15. Yao, S., Zhang, D., Chen, X., Lu, F., \& Wang, W. (2016). Experimental and numerical study on the dynamic response of RC slabs under blast loading. Engineering Failure Analysis, 86, 120-129. DOI: https//doi.org/10.1016/j.engfailanal.2016.04.027.

16. ABAQUS standard user's manual. Ver. 6.10-1. (2010).

17. Orakcal, K., Massone, L.M., \& Wallace, J.W. (2006). Analytical modelling of reinforced concrete walls for predicting flexural and coupled-shear-flexural responses. University of California, Los Angeles. PEER report.

18. Shima, H, Chou, L, \& Okamura, H. (1987). Micro and macro models for bond in reinforced concrete. Journal of Faculty of Engineering, 39, 2, 133-94.

19. May, G.C., \& Smith, P.D. (1995). Blast effects on buildings. Thomas Telford Ltd., London, E14 4 JD.

20. Wu, C., Oehlers, D.J., Rebentrost, M., Leach, J., \& Whittaker, A.S. (2009). Blast testing of ultra-high performance fiber and FRP-retrofitted concrete slabs. Journal of Engineering Structures, 31, 9, 20602069. DOI: https//doi.org/10.1016/j.engstruct.2009.03.020.

21. Jones, J., Wu, C., Oehlers, D.J., Rebentrost, M., Leach, J., Whittaker, A.S., Sun, W., Marks, S., \& Coppola, R. (2009). Finite difference analysis of simply supported RC slabs for blast loadings. Journal of Engineering Structures, 31, 12, 2825-2832. DOI: https//doi.org/10.1016/j.engstruct.2009.07.011.

Ахмад Рахбар Ранджи, Ahmad Rahbar Ranji, ORCID: https://orcid.org/0000-0002-7056-929X

Азар Есмаелі, Azar Esmaeli

Received August 19, 2018

Accepted October 12, 2018 